\title{
Fish Farmers' Attitude Toward Agricultural Insurance Scheme in Ondo State Nigeria
}

\section{Oladipo Felix Olayinka}

Department of Agricultural Extension and Rural Development, University of Ilorin, llorin, Nigeria

Email: felixoladipo5@gmail.com

Phone: +2348032275101

\section{Olayode, Olawunmi Oluwafunmilola}

Department of Agricultural Extension and Rural Development, University of Ilorin, Ilorin, Nigeria

Email:wefotex@gmail.com

Phone: +2347039723948

\section{Adesoji, Solomon Adedapo}

Department of Agricultural Extension and Rural Development, Obafemi Awolowo University, Ile Ife, Nigeria,

Email: dapadesoji@yahoo.co.uk

Phone: +2348035605062

\section{Daudu, Abdulrasaq Kamal}

Department of Agricultural Extension and Rural Development, University of Ilorin, Ilorin, Nigeria

Email: daudu.ak@unilorin.edu.ng

\section{Abstract}

The study assessed fish farmers' attitude towards agricultural insurance scheme (AIS) in Ondo State, Nigeria. A multi-stage sampling procedure was adopted to select the respondents for the study. Data were obtained through questionnaire and were analysed using descriptive statistics and mean score from a five point Likert type of scale. The study showed the mean age of fish farmers to be $44.6 \pm 10.1$ years and the majority (83.4\%) were married. The mean household size was $5 \pm 2$ and about $96 \%$ were able to read and write. The mean years of fish farming experience was 13.54 and all of them were smallholders. More than half (57.3\%) of the respondents had neutral attitude, 23.7 per cent had favourable attitude while 19 per cent had unfavourable attitude towards AIS. They perceived that insurance belongs to God and not any insurance company $(\mu=1.8)$ and that small scale farmer do not really need to insure their farms, $(\mu=1.8)$. The study recommended that the respondents should be empowered to increase their scale of fish production as this might change their attitude to the scheme. Also, government should re-subsidize agricultural insurance to enable serious farmers afford the premium.

Key words: Fish Farmers, Attitude, Agricultural Insurance Scheme 
Creative commons User License: CC BY-NC-ND

Abstracted by: EBSCOhost, Electronic Journals Service (EJS), Google Scholar, Journal Seek, Scientific Commons,

Food and Agricultural Organization (FAO), CABI and Scopus
Journal of Agricultural Extension

Vol. 22 (3) October, 2018

ISSN(e): 24086851; ISSN(Print); 1119944X

http://journal.aesonnigeria.org

http://www.ajol.info/index.php/iae

Email: editorinchief@aesonnigeria.org

\section{Introduction}

Agricultural production faces myriad of risks than most other enterprises (Epetimehin, 2010). Risks in Agriculture are most certainly not independent of nature. This is because they go beyond all the well-known and researched entrepreneurial hazards and uncertainties of modern world. Owing to the fact that economic growth and agricultural growth are tied to each other, managing risks in agriculture is a big challenge to both the policy makers and researchers. Nevertheless, two major risks are of concern to the agricultural sector; these are price risk which is caused by potential volatility in prices and production risk resulting from uncertainty about the levels of production that primary producer can achieve from their current activities (Ramiro, 2009). He further posited that it is likely that these major risks will increase in the future- price risk due to liberalization of trade and production risk caused by the effects of climate change. Disasters can often not be prevented from happening but they can, to some extent, be predicted and arrangements can be made to reduce their impact. However, in some cases, disasters cannot be predicted and farmers will have to cope with major losses after the occurrence of the event. The trend towards agricultural specialization is likely to continue which will increase these risks as producers rely on the production of a smaller range of crops and consequently cannot diversify risks as effectively.

Agricultural insurance is considered an important mechanism to effectively address the risk to output and income resulting from various natural and manmade events (Lawal, B.O. and Ajayi, A.O, 2014). Agricultural insurance is a means of protecting farmers against financial losses due to uncertainties that may arise from named or all unforeseen perils beyond their control (Mojarradi, G.R., Zamani, G.H., Zarafshani, K., 2008; Suresh, D., Barahb, B.C., Ranganathana, C.R., Venkatrama, R., Gurunathana, S., Thirumoorthy, S.,2011). It is a method by which farmers can stabilize farm income and investment and guard against disastrous effect of losses due to natural hazards or low market. However, insurance is not the universal solution to the risk and uncertainties that farmers face. It can only address part of the losses resulting from some perils and is not a substitute for good on-farm risk-management techniques, sound production and farm management practices and investments in technology (Food and Agriculture Organization, 2013).

Attitude is a situation whereby farmers behave consistently favourable or unfavourable towards an object, product or service (Adah, 2015). He stated that it is the more or less permanent feelings, thoughts and predispositions a person has about certain aspects of his environment. Most agricultural programmes and innovations fade off after their pilot stage due to lack of interest on the part of the providers (Wixson and Katchoya, 2011) and low willingness to pay (demand) for the services or products (Enjolras and Adinolfi, 2013; Mahul, and Stutley, 2010), a behaviour influenced by farmers' attitude.

Eleri, O. E., Uduka, I. K., Akuto, N., Onuvae, P., Anwara, O (2012) and Patrick, (2010) opined that since farmers cannot predict the probability of occurrence of any of these and cannot bear these risks and uncertainties alone, they are faced with the option of transferring or sharing the risks involved in the day-to-day management of their farms with one or more individuals or firms. In view of the risks and uncertainties of 
Creative commons User License: CC BY-NC-ND

Abstracted by: EBSCOhost, Electronic Journals Service (EJS), Google Scholar, Journal Seek, Scientific Commons,

Food and Agricultural Organization (FAO), CABI and Scopus
Journal of Agricultural Extension

Vol. 22 (3) October, 2018

ISSN(e): 24086851; ISSN(Print); 1119944X

http://journal.aesonnigeria.org

http://www.ajol.info/index.php/iae

Email: editorinchief@aesonnigeria.org

agricultural production in Nigeria, the Federal Government of Nigeria launched the Nigerian Agricultural Insurance Scheme (NAIS) on the 15th December, 1987 and the Nigeria Incentive-Based Risk Sharing System for Agricultural Lending (NIRSAL) in June, 2011 as part of governments' efforts to enhance food production in Nigeria. Agricultural insurance looks into how risks and uncertainties can be effectively managed to the advantage of the farmers in the present and also in the future. Agricultural insurance is a necessary part of the institutional infrastructure essential for the development of agriculture, which is mainly a high risk enterprise. It also control lending environment for banks in which the agricultural value chain is well structured (Emmanuel, 2007, National Agricultural Extension Research Liaison Services, 1991).

Despite the challenges such as extreme climatic conditions, flood, water pollution, lack of adequate technology, fish diseases, problems of preservation, poor marketing, high cost of inputs and inadequate extension contact, etc. confronting fish farming in Nigeria, and agricultural insurance scheme being one of the strategies put in place to mitigate these challenges, there is dearth of information concerning the attitude of fish farmers in agricultural insurance Scheme, hence this study. The specific objectives of the study are to describe the socio-economic characteristics of fish farmers and to determine their attitude towards agricultural insurance scheme in the study area. It was hypothesized that there was no significant relationship between fish farmers' socio-economic status and their attitude to agricultural insurance scheme.

\section{Methodology}

The study was conducted in Ondo State of Nigeria. Men, women and youths involved in fish farming in Ondo State constituted the population from which the study sample was drawn. Multi-stage sampling procedure was adopted to select the respondents for the study. Ondo State is divided into four agricultural zones namely; Ondo zone, Owo zone, Ikare zone and Okitipupa zone. At the first stage, two LGAs were purposively selected from each of the four agricultural zones based on their pronounced involvement in fish farming. The second stage involved a random selection of two communities from each of the selected LGAs making a total of sixteen communities. The last stage was a proportionate sampling of 20 percent of the fish farmers in the sixteen communities making a total of 295 respondents out of 1728 registered fish farmers in Ondo State.

Questionnaire was used to elicit quantitative data from the respondents. Data collected were summarized with percentages, mean, standard deviation. Chi-square, correlation and regression analyses were employed to draw inferences.

\section{Results and Discussions}

\section{Farmers' Demographic Characteristics}

Table 1 shows the distribution of respondents by demographic characteristics. The result shows that the mean age of fish farmers in Ondo State was $44.6 \pm 10.1$ years. The findings showed that above average (58.6\%) of fish farmers in Ondo State were still in their active years of life in which they could still be productive and contribute to the socio-economic wellbeing of the society. This age could influence their attitude to agricultural insurance scheme as young people are ready to try something new or 
Creative commons User License: CC BY-NC-ND

Abstracted by: EBSCOhost, Electronic Journals Service (EJS), Google Scholar, Journal Seek, Scientific Commons,

Food and Agricultural Organization (FAO), CABI and Scopus
Journal of Agricultural Extension

Vol. 22 (3) October, 2018

ISSN(e): 24086851; ISSN(Print); 1119944X

http://journal.aesonnigeria.org

http://www.ajol.info/index.php/iae

Email: editorinchief@aesonnigeria.org

better still take risk. This finding is in line with that of Nnadi, F. N., Nnadi, C. D., Chikaire, J., Umunnakwe, P. C., Ihenacho, R. A.,(2013), that participants of agricultural insurance were younger, and were more disposed to participating in Nigerian agricultural insurance scheme. This could be explained by their higher venturesomeness, innovativeness and more risk proneness. Also, Okunlola, J. O., Oludare, A. O., Akinwalere, B. O.,(2011) reported that most fish farmers were middle aged, agile and active to withstand the rigors of fish farming. About $78 \%$ of the respondents were male while the remaining 22.0 per cent were female. The result indicated that there were more men in fish farming than women in the study area. This finding is similar to that of Adebo G. M. and. Ayelari T. A (2011) that $80 \%$ of fish farmers were men. Since most of the fish farming activities requires time and energy which women might not be able to effectively cope with because of other responsibilities as housewife.

Table 1: Distribution of respondents by demographic characteristics

\begin{tabular}{lll}
\hline Demographic characteristics & Percentage (n= \\
\hline Age & & \\
Below 31 & 8.2 & Mean=45 \\
$31-40$ & 31.7 & SD $=10$ \\
$41-50$ & 26.9 & \\
Above 50 & 33.2 & \\
Sex & & \\
Male & 78.0 & \\
Female & 22.4 & \\
Religion & & \\
Christian & 94.5 & \\
Islam & 4.5 & \\
Traditional & 1.0 & \\
Marital status & & \\
Single & 14.1 & \\
Married & 83.4 & \\
Separated & 0.3 & \\
Widow(er) & 2.0 & \\
Household size & & \\
Below 6 & 67.2 & Mean=5 \\
6-10 & 31.7 & SD=2 \\
Above 10 & 1.0 & \\
**Literacy level & & \\
Can only read & 96.3 & \\
Can read and write & 95.9 & \\
Years of formal education & & \\
Below 7 & 10.8 & \\
7-12 & 15.6 & \\
13 and above & 73.6 & \\
Level of formal education & & \\
No formal Education & 1.7 & \\
Adult Education & 6.4 & \\
Completed Primary Education & 8.8 & \\
Uncompleted Primary Education & 2.4 & \\
Completed Primary Education & 72.2 & \\
Tertiary Education & & \\
& &
\end{tabular}


Creative commons User License: CC BY-NC-ND

Abstracted by: EBSCOhost, Electronic Journals Service (EJS),

Google Scholar, Journal Seek, Scientific Commons,

Food and Agricultural Organization (FAO), CABI and Scopus
Journal of Agricultural Extension

Vol. 22 (3) October, 2018

ISSN(e): 24086851; ISSN(Print); 1119944X

http://journal.aesonnigeria.org

http://www.ajol.info/index.php/iae

Email: editorinchief@aesonnigeria.org

Years of fish farming experience

Below 11

11-20

58.3 Mean $=14$ years

$21-30$

$20.3 \mathrm{SD}=12$

Above 30

9.2

11.9

Source: Field survey, 2015

About $94 \%$ and $4.7 \%$ of the respondents were Christians and Muslims, respectively while very few $(1.0 \%)$ practised traditional religion. Despite the fact that all the respondents belong to one religion affiliation or the other, the majority (94.2\%) still belonged to Christianity. This implied that Christianity might be the dominant religion in the study area. Religion affiliation could be a useful indicator in identifying and mobilizing fish farmers for meaningful participation in agricultural insurance. This is because farmers could easily interact with people of their faith and in doing so, they could discuss ideas related to agriculture.

A majority (83.4\%) of the respondents were married. This implied that the majority of the respondents were married and were expected to be responsible because marriage is considered as respected institution where married people are regarded as mature and responsible with divorce being a culturally rare occurrence due to the stigmatization attached to it. With the majority of the respondents being married, the implication is that they would have more responsibility to meet up with as household members increase through procreation. Also, family member(s) have been a source of labour especially in fish farming operations, they could be a source of information and they could even be persuaded to participate in the scheme.

About $68 \%$ of the respondents had household size of less than 6 members, while $31.5 \%$ had between 6 and10 members within their household while very few $(1.0 \%)$ had above 10 members. Mean household size was approximately 5 people. The result indicated that most of the respondents had household size of less than 6 members. This might be as a result of the economic situation of the country, education and high rate of unemployment leading many people into family planning so as to reduce birth rate. It might also be due to the fact that the traditional orientation of marrying more than a wife at a time and bearing as many children as possible as a sign of wealth is constantly fading away in the study area (Adesoji S.A, Olayode 0.0 and Ogundeji A. O., 2017). Since a majority of the respondents $(59.3 \%)$ had at least 5 persons and the mean household size was $5 \pm 2$, a considerable amount of labour could be derived from within the household to provide help on fish farm when needed. Division of labour could occur during fish farming activities so that more could be done within a short period and with less energy exertion.

About $96 \%$ of the respondents could only read while $95.9 \%$ could read and write. Also, about $10.8 \%$ of the respondents had less than 7 years of formal education, 15.6 $\%$ had $7-12$ years while $73.6 \%$ had more than 12 years of formal education. It further revealed that 72.2 per cent had post-secondary school education. This means that a majority $(99 \%)$ of the respondents had one form of formal education. This high level of literacy could influence their attitude to Nigerian Agricultural Insurance Scheme. This finding corroborates Alfred, S. D. Y and. Fagbenro O.A(2015) assertion that high 
level of literacy could be regarded as an advantage for the choice of source of information for fish production. Also, Okunlola (2009) and Agbamu (2006) stated that educational level is one of the factors that influenced adoption of new technology by farmers.

Above average (58.6\%) of the respondents had at most 10 years of fish farming experience, $20.3 \%$ had between 11 and 20 years of fish farming experience while $11.9 \%$ had more than 30 years of fish farming experience. The mean years of fish farming was $13.54 \pm 11.91$ years. This is in contrast to the view of Alfred, S. D. Y., Fagbenro, O. A. (2015) assertion that above average (56\%) of fish farmers in Ondo State had been into fish farming for over 10 years. The reasons might be due to new agricultural programmes such as agricultural transformation agenda which might encourage youth to take agriculture and the recent discovery that fish farming is a lucrative enterprise. Also, unemployment rate might make most youth to drift to fish farming. Some of the farmers had started fish farming since their childhood most especially those in the riverine area of the State. Since about $42 \%$ of the respondents had more than 10 years of fish farming experience, they would have encountered one or more challenges associated with fish farming and this would prompt them to have favourable attitude towards agricultural insurance policy which is one of the strategies put in place to cushion these challenges.

Fish Farmers' Attitude towards Agricultural Insurance Scheme.

Table 2 shows that AIS was meant to protect farm against risk and reduces farmers' worries and stress ranked first with mean value of 2.0. 
Creative commons User License: CC BY-NC-ND

Abstracted by: EBSCOhost, Electronic Journals Service (EJS),

Google Scholar, Journal Seek, Scientific Commons,

Food and Agricultural Organization (FAO), CABI and Scopus
Journal of Agricultural Extension

Vol. 22 (3) October, 2018

ISSN(e): 24086851; ISSN(Print); 1119944X

http://journal.aesonnigeria.org

http://www.aiol.info/index.phpliae

Email: editorinchief@aesonnigeria.org

Table 2: Attitude of respondents towards agricultural insurance scheme Attitude

\begin{tabular}{|c|c|c|}
\hline Agricultural Insurance scheme is meant to protect farm against risk & 2.0 & $1^{\text {st }}$ \\
\hline Insurance belongs to God and not any insurance company & 1.8 & $2^{\text {nd }}$ \\
\hline I am aware that Insurance has a lot of benefits for both small and large scale farmers. & 1.8 & $2^{\text {nd }}$ \\
\hline Small scale farmer do not really need to insure their farms & 1.8 & $2^{\text {nd }}$ \\
\hline Agricultural Insurance is meant for all farmers regardless of the type of production & 1.8 & $2^{\text {nd }}$ \\
\hline Agricultural insurance is good for loan beneficiaries in the wake of failure of production & 1.6 & $3^{\text {rd }}$ \\
\hline Agricultural Insurance covers and pays for most of the damages experienced by farmers & 1.6 & $3^{\text {rd }}$ \\
\hline Only large scale farmers can buy insurance policy with the conditions & 1.5 & $4^{\text {th }}$ \\
\hline Agricultural insurance Scheme is very reliable & 1.5 & $4^{\text {th }}$ \\
\hline I have learnt to bear my own risk and do not need any insurance & 1.5 & $4^{\text {th }}$ \\
\hline Insurance companies are group of paper robbers & 1.3 & $5^{\text {th }}$ \\
\hline Agricultural Insurance is a deceit of the government and is meant to siphon farmers' money & 1.3 & $5^{\text {th }}$ \\
\hline Practicing agricultural insurance is a waste of time & 1.3 & $5^{\text {th }}$ \\
\hline With Agricultural Insurance, I can expand my agricultural production & 1.3 & $5^{\text {th }}$ \\
\hline Agricultural Insurance stabilizes the agricultural industry & 1.3 & $5^{\text {th }}$ \\
\hline $\begin{array}{l}\text { With Agricultural Insurance, I am less worried about the incidence of pests and notable diseases } \\
\text { on my fish farm }\end{array}$ & 1.2 & $6^{\text {th }}$ \\
\hline $\begin{array}{l}\text { Agricultural Insurance alleviates the problem of collateral security often demanded as guarantee } \\
\text { for loans }\end{array}$ & 1.2 & $6^{\text {th }}$ \\
\hline Insurance enables existing businesses to remain in operation & 1.1 & $7^{\text {th }}$ \\
\hline Insurance do not cater for most risks experienced by farmers & 1.1 & $7^{\text {th }}$ \\
\hline There is excessive bureaucratic processes in the operation of Agricultural insurance & 1.1 & $7^{\text {th }}$ \\
\hline Insurance companies would only cheat farmers at the end of the day & 1.1 & $7^{\text {th }}$ \\
\hline Constraints associated with agricultural insurance far outweighs its benefit & 1.1 & $7^{\text {th }}$ \\
\hline Insurance companies do not pay indemnity whenever they have to do so & 1.0 & $8^{\text {th }}$ \\
\hline Insurance is very costly to operate & 1.0 & $8^{\text {th }}$ \\
\hline Agricultural Insurance enhances agricultural households' welfare & 1.0 & $8^{\text {th }}$ \\
\hline Agricultural insurance involves too much laws and cannot be fully understood because of clauses & 0.9 & $9^{\text {th }}$ \\
\hline You need to know somebody before you can have your claim & 0.8 & $10^{\text {th }}$ \\
\hline Government is adequately funding agricultural insurance & 0.7 & $11^{\text {th }}$ \\
\hline
\end{tabular}

Source; Field survey, 2015 
Creative commons User License: CC BY-NC-ND

Abstracted by: EBSCOhost, Electronic Journals Service (EJS), Google Scholar, Journal Seek, Scientific Commons,

Food and Agricultural Organization (FAO), CABI and Scopus
Journal of Agricultural Extension

Vol. 22 (3) October, 2018

ISSN(e): 24086851; ISSN(Print); 1119944X

http://journal.aesonnigeria.org

http://www.ajol.info/index.php/iae

Email: editorinchief@aesonnigeria.org

This implied that the majority $(60.3 \%)$ of the respondents were of favourable disposition to AIS meant to protect farm against risk and reduces farmers' worries and stress. The finding contradicts that of Lawal, B.O. and Ajayi, A. O, (2014) which reported that the majority of the respondents in his study area did not agree with the insinuation that agricultural insurance was meant to protect farm against risk and reduce farmers' worries and stress

These were followed by the following statements: insurance belongs to God and not any insurance company, small scale farmer does not really need to insure their farms, agricultural insurance is meant for all farmers regardless of the type of production, and awareness that insurance has a lot of benefits for both small and large scale farmers. This implied that about half $(48.8 \%)$ of the respondents agreed that insurance had a lot of benefits for both small and large scale farmers. This finding contradicts that of Lawal et. al. (2014) which reported that the majority of the farmers disagreed with the allusion that insurance has a lot of benefits for both small and large scale farmers.

Agricultural insurance is good for loan beneficiaries in the wake of failure of production and Al covers and pays for most of the damage experienced by farmers ranked $3^{\text {rd }}$ with mean value of 1.6. Only commercial farmers can buy insurance policy with the condition ranked $4^{\text {th }}$ as well as agricultural insurance scheme is very reliable. Also, fish farmers had learnt to bear their risk and did not need insurance ranked $4^{\text {th }}$. This implies that above average (55\%) of the respondents had other means to reduce the risks in fish farming. Five of the statements ranked $5^{\text {th }}$ with mean value of 1.3. These are; insurance companies are group of paper robbers, agricultural insurance is a deceit of the government and is meant to siphon farmers' money, practising agricultural insurance is a waste of time, agricultural insurance stabilizes the agricultural industry and with agricultural insurance, I can expand my agricultural production. The finding underscored the need for more enlightenment of the respondents about the importance of their participation in AIS. Also, only two of the statements ranked $6^{\text {th }}$ with mean value of 1.2 and these are; with agricultural insurance, I am less worried about the incidence of pests and notable diseases on my fish farm and I have access to credit from formal institutions because agricultural insurance alleviates the problem of collateral security often demanded as guarantee for loans. Insurance companies would only cheat farmers at the end of the day and there is excessive bureaucratic process in the operation of agricultural insurance ranked $7^{\text {th }}$. Also, constraints associated with agricultural insurance far outweighs its benefit, insurance does not cater for most of the risks experienced by farmers and insurance enables existing businesses to remain in operation and it encourages new ones to spring up thus guaranteeing continuous and sustainable economic growth ranked $7^{\text {th }}$ as well with mean value of 1.1 . This implied that very few $(14.9 \%)$ of the respondents agreed that the constraints associated with agricultural insurance scheme far outweighed.

Furthermore, agricultural insurance enhances agricultural households' welfare which can possibly translate to general economic development, insurance is costly to operate and insurance companies do not pay indemnity whenever they have to do so ranked $8^{\text {th }}$ with mean value of 1.0 . This implied that very few $(22.7 \%, 25.1 \%$ and 
$28.1 \%$ ) of the respondents were of positive disposition to the assertions. Also, about $25 \%$ of the respondents saw insurance as costly to operate, this means that some of the fish farmers needed to know that payment of premium was based on the volume of one's investment. The more the worth of one's investment, the more the premium to be paid, although at a subsidized rate. Hence, fish farmers still need to be enlightened that insurance was more beneficial to them and that it gave them peace of mind whenever there was disaster, the loss would not be total as NAIC would indemnify such farmer.

\section{Level of Attitude Towards Agricultural Insurance Scheme}

Figure 1 reveals that more than half $(57.3 \%)$ of the respondents had neutral attitude, $23.7 \%$ had favourable attitude while $19 \%$ had unfavourable attitude towards AIS in the study area which would affect their participation in the scheme. This implied that fish farmers in the study area still need enlightenment on the benefit of participation in AIS.

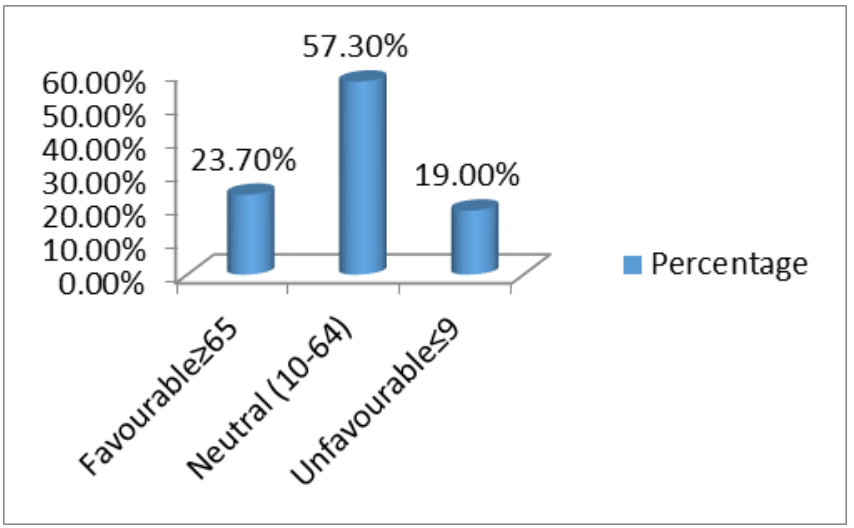

Mean Score $=37.04$

Standard deviation $=27.5$

Source; Field survey, 2015

\section{Figure 1: Histogram showing respondents by their level of attitude towards agricultural insurance scheme}

\section{Factors Affecting Attitude Toward Agricultural Insurance Scheme}

Table 3 shows that of all the variables subjected to multiple regressions, only six were found to be significant predictors. The $R$ value of 0.710 indicates that the selected variables had strong correlation on the level of fish farmers' attitude towards AIS; About $50 \%$ of the variation in the dependent variable was explained by the independent variable $\left(R^{2} 0.505, p \leq 0.05\right)$. 
Creative commons User License: CC BY-NC-ND

Abstracted by: EBSCOhost, Electronic Journals Service (EJS), Google Scholar, Journal Seek, Scientific Commons,

Food and Agricultural Organization (FAO), CABI and Scopus
Journal of Agricultural Extension

Vol. 22 (3) October, 2018

ISSN(e): 24086851; ISSN(Print); 1119944X

http://journal.aesonnigeria.org

http://www.ajol.info/index.php/iae

Email: editorinchief@aesonnigeria.org

Table 3: Relationship between the socio economic characteristics and the attitude of fish farmers to AIS

\begin{tabular}{llll}
\hline Model & B & B & T \\
\hline Constant & 22.927 & & 1.221 \\
Awareness & 1.880 & 0.461 & $7.472^{* *}$ \\
Age of respondent & 1.073 & 0.040 & 0.672 \\
Years of awareness & 8.397 & 0.121 & $2.061^{* *}$ \\
Number of fish ponds & 10.014 & 0.091 & 1.846 \\
Number of years spent in school & -0.543 & -0.013 & -0.242 \\
Number of sources of information & -0.587 & -0.059 & -1.108 \\
Number of association belonged & 1.764 & 0.077 & 1.470 \\
to & & & \\
Frequency of travel & 0.035 & 0.003 & 0.059 \\
Number of sources of capital & -0.573 & -0.224 & $-4.088^{* *}$ \\
Number of fish types reared & 4.698 & 0.113 & 1.921 \\
Income from fish farming & 2.042 & 0.083 & 1.279 \\
Income from other farming & 4.416 & 0.030 & 0.589 \\
activities & & & \\
Income from other occupation & -8.965 & -0.159 & $-2.735^{\star *}$ \\
Years in fish farming & -6.773 & -0.241 & $-4.153^{\star *}$ \\
Farm size & 1.904 & 0.049 & 0.912 \\
Amount paid per annum on farm & 33.700 & 0.131 & $2.704^{* *}$ \\
rent & & & \\
Household size & 4.679 & 0.082 & 1.390 \\
Number of contact with extension & 0.063 & 0.012 & 0.234 \\
agent & & & \\
\hline
\end{tabular}

** $\mathrm{P} \leq 0.05$.

Source; Field survey, 2015

Number of sources of capital $(b=-0.224)$, income from other occupation $(b=-0.159)$, and years in fish farming $(b=-0.241)$, were significant $(\leq 0.05)$ and negatively contributed to fish farmers' attitude towards AIS. Numbers of years of awareness $(b=0.121)$, awareness of AIS $(b=0.461)$ and payment of farm rent annually $(b=-$ 0.251 ) was significant were significant $(\leq 0.05)$ and positively contributed to the level of fish farmers' attitude towards AIS. These six variables are crucial in explaining fish farmers' attitude towards agricultural insurance scheme (AIS). This implies that anytime level of fish farmers' attitude towards AIS would want to be determined, these six variables should be carefully considered. Considering the magnitude of regression for each of the significant variable, a relationship is thus formed from the equation $\mathrm{Y}=\mathrm{a}+\mathrm{b} 1 \mathrm{X} 1+\mathrm{b} 2 \mathrm{X} 2+\mathrm{b} 3 \mathrm{X} 3+\mathrm{b} 4 \mathrm{X} 4+\mathrm{b} 5 \mathrm{X} 5+\mathrm{b} 6 \mathrm{X6}+\mathrm{e} 0$

$Y=1.221+0.461(7.472)+0.121(2.061)-0.224(-4.088)-0159(-2.735)-0.241(-4.153)$ $+0.131(2.704)$

\section{Conclusion and Recommendations}

Fish farmers in Ondo State had neutral attitude to agricultural insurance scheme. The respondents should be empowered to increase their scale of fish production as this 
might change their attitude to the scheme. NAIC should readily indemnify an insured farmer whenever there is disaster.

\section{References}

Adah,O.C.(2015). Adoption analysis of improved oil palm fruit processing technology in Kogi State,Nigeria. Ph.D Thesis. Department of Agricultural Economics and Extension, Kogi State University, Anyigba, Nigeria. 14.

Adebo G. M. and. Ayelari T. A (2011): Climate change and vunerability of fish farmers in Southwestern Nigeria. African Journal of Agricultural Research Vol. 6(18), $\quad$ pp. 42304238, Available online at http://www.academicjournals.org/AJAR. DOI: 10.5897/AJAR10.948 ISSN 1991-637X

Adesoji S.A, Olayode O.O and Ogundeji A. O. (2017). Evaluating the participation level of fish farmers in agricultural insurance scheme in Ondo State, Nigeria. Scientific Papers Series Management, Economic Engineering in Agriculture and Rural Development Vol. 17 , Issue 4

Agbamu, J.U.(2006). Essentials of agricultural communication in Nigeria. Lagos, Malthouse Press Limited. 47-81.

Alfred, S. D. Y and. FagbenroO.A (2015): Perception Of Tilapia Farmers On Information Sources In The Coastal Region Of Ondo State, Nigeria.

Eleri, O. E., Uduka, I. K., Akuto, N., Onuvae, P., Anwara, O., (2012). Towards a Climatebased Agricultural Insurance Reform in Nigeria. Presented at the Workshop on Legal and Regulatory Frameworks for Agricultural Insurance Reform in Nigeria-Protecting Nigeria's Farmers from Climate Change Kano Hall,Transcorp Hilton Hotel,February 27, 2012.pp.1-53

Emmanuel, K., (2007). Cashing in on the Advantages of the Nigerian Insurance Agricultural Corporation.http: $\quad$ www.ngex.com/news/public/article.php?ArticlelD=2 36 , Retrieved on the 24th April 2012.

Enjolras, G., Capitanio, F. and Adinolfi, F. (2012).The demand for crop insurance: Combined approaches for France and Italy. Agri. Eco. Rev. 13(1): 5-22.

Epetimehin, Festus M. (2010). Agricultural Insurance In Nigeria And Its Economic Impact. Joseph Ayo Babalola University IkejiArakeji. Also Available at SSRN:http://ssrn.com/abstract=1602926 or http://dx.doi.org/10.2139/ssrn.1602926,

Accessed on August 29th, 2014

Food and Agriculture Organization (2013).available at: http://www.fao.org/tc/tca/work05/ nigeriappt.pdf, Accessed on August 29th, 2014

Lawal, B.O. and Ajayi, A. O, (2014): Farmers' awareness and perception of agricultural insurance in Oyo State, Nigeria. Spanish Journal of Rural Development, Vol. V (1):,Ignacio J. Díaz- Maroto Hidalgo DOI: 10.5261/2014. GEN1.03 
Creative commons User License: CC BY-NC-ND

Abstracted by: EBSCOhost, Electronic Journals Service (EJS),

Google Scholar, Journal Seek, Scientific Commons,

Food and Agricultural Organization (FAO), CABI and Scopus
Journal of Agricultural Extension

Vol. 22 (3) October, 2018

ISSN(e): 24086851; ISSN(Print); 1119944X

http://journal.aesonnigeria.org

http://www.ajol.info/index.php/iae

Email: editorinchief@aesonnigeria.org

Mahul, O. and Stutley, C.J. (2010) Government support to agricultural insurance: Challenges and options for developing countries. Washington D.C., World Bank Publications.

Mojarradi, G.R., Zamani, G.H., Zarafshani, K. 2008. Analysis of factors influencing farmers' attitude towards private crop insurance using path analysis.

American-Eurasian Journal of Agriculture and Environmental Science 3 (2): 247- 252.

National Agricultural Extension Research Liason ServicesNAERLS (1991). Practices of Agricultural Insurance in Nigeria. Extension Bulletin. No. 10, Abuja, Nigeria. NAERLS.

Nnadi, F. N., Nnadi, C. D., Chikaire, J., Umunnakwe, P. C., Ihenacho, R. A., (2013). Analysis of Rural Cassava Farmers' Participation in the Nigeria Agricultural Insurance Scheme in Imo State, Nigeria Global Journal of Science Frontier

Research Agriculture and Veterinary, 13(11) Version 1.0., pp.1-8.

Okunlola, J.O. (2009). Factors influencing Adoption of Rubber Based Technologies among Small Holder Farmers in Delta state Nigeria International Journal of Food Agriculture and $\quad$ Environment Helsinki, Finland 7:2.

Okunlola, J. O., Oludare, A. O., Akinwalere, B. O., (2011). Adoption of new technologies by fish farmers in Akure, Ondo state, Nigeria. Journal of Agricultural Technology 7(6): $1539-1548$

Patrick, C. A., (2010). Poultry Farmers' Response to Agricultural Insurance in Delta State, Nigeria, Journal of Agricultural Sciences 1(1): 43-47

Ramiro, I., 2009, Premier Series on Insurance. Issue 12, November 2009.

Wixson, S.E. and Katchova, A.L. (2011). Price asymmetric relationships in the commodity and energy markets. University of Kentucky. 